\title{
THERMOINHIBITION IN PARSLEY SEEDS
}

\author{
TERMOINIBIÇÃO EM SEMENTES DE SALSA
}

\author{
Tiago Alexandre da SILVA ; Luiz Felipe Guedes BALDINI²; Gisela FERREIRA³ \\ João NAKAGAWA ${ }^{1}$; Edvaldo Aparecido Amaral da SILVA ${ }^{1}$ \\ 1. Departamento de melhoramento e produção vegetal, UNESP, Botucatu, SP, Brasil; 2. Departamento de horticultura, UNESP, \\ Botucatu, SP, Brasil; 3. Instituto de Biociências, UNESP, Botucatu, SP, Brasil. tiago.at.agro@ hotmail.com
}

\begin{abstract}
Temperature can exert great influence on germination, being considered optimal the temperature in which seed expresses its maximum germination potential in the shortest period of time. The germination of parsley seeds is slow, irregular and uneven. The aim of this study was to determine whether there is occurrence of thermodormancy or thermoinhibition of parsley seeds as a function of temperature variations. The experimental design of the first stage was completely randomized (CRD) consisting of 7 temperatures and 4 replicates and the second stage in a $3 \times 3$ factorial scheme consisting of 3 parsley cultivars and 3 germination temperatures with 4 replicates. Seeds of the different cultivars did not germinate at temperature of $35^{\circ} \mathrm{C}$. Parsley seeds showed thermoinhibition at high temperatures, being necessary to elucidate the mechanisms involved in this process.
\end{abstract}

KEYWORK: Temperature. Physiological potential. Petroselinum crispum.

\section{INTRODUCTION}

Parsley (Petroselinum crispum) is an herbaceous vegetable of the apiacea family, adapted to mild temperatures, being sown in the autumnwinter or throughout the year in high regions. Parsley does not stand out for volume or value marketed, but for its wide commercial use as a condiment (RODRIGUES et al. 2008).

Leafy vegetable species of direct sowing in the field are more affected by unfavorable weather conditions such as excessive rainfall and high solar irradiation (NASCIMENTO, 2005), and, depending on temperature and soil water availability, seedling emergence in the field is relatively time consuming. The slow and uneven germination of parsley seeds (PILL; KILIAN, 2000) combined with unfavorable weather conditions leads to serious losses in the formation of the plant stand.

Temperature is one of the factors that most affect the performance of vegetable seeds, as it influences the water absorption rate and biochemical reactions that determine the germination process (MACHADO et al. 2002). Filgueira (2008) points out that seed germination, emergence and early seedling development are directly conditioned by temperature.

The optimum temperature conditions are those that accelerate germination without reducing the percentage of germinated seeds. Germination generally occurs under certain temperature limits (for example, $10^{\circ} \mathrm{C}$ and $30^{\circ} \mathrm{C}$ ), with temperature considered optimal within these limits (for example, $25^{\circ} \mathrm{C}$ ), in which there is maximum number of seeds germinated within minimum time period (DINIZ et al, 2008); for parsley seeds, optimal temperature is $20^{\circ} \mathrm{C}$ (BRASIL, 2009).

According to Bewley et al. (2013) germination results of a series of biochemical reactions highly dependent on temperature. This temperature range varies among different species. Above and below maximum and minimum limits, respectively, death or seed dormancy may occur. Studies have reported that temperatures between 20 and $30^{\circ} \mathrm{C}$ is optimum for the germination of leafy vegetables (PEREIRA et al., 2007; FERREIRA et al., 2008; STEINER et al., 2009).

High temperatures can affect germination during seed imbibition resulting in thermoinhibition, a reversible process, i.e., seeds will germinate if temperature returns to adequate level; and thermodormancy, in which seeds will not germinate even with return of temperature to adequate levels (KHAN, 1980/81).

Considering these facts, the aim of this work was to study the effect of temperature on parsley seed germination (Petroselinum crispum) and whether there is occurrence of thermodormancy or thermoinhibition.

\section{MATERIAL AND METHODS}

The experiment was conducted in two stages at the Laboratory of Seeds, Department of Production and Plant Breeding, Faculty of Agricultural Sciences - UNESP / Botucatu. Commercial parsley seeds cultivars Graúda Portuguesa, Lisa Preferida and Chácara were used. 
Stage 1 - Parsley seed germination at different temperatures: Seeds of Graúda Portuguesa cultivar were submitted to temperatures of $10,20,25,30,35^{\circ} \mathrm{C}$ and alternating temperatures of $20-30$ and $30-20^{\circ} \mathrm{C}$ during germination and evaluated by the following methods:

Germination test: performed with four replicates of 100 seeds arranged in germitest paper substrate in gerbox plastic boxes moistened with $10 \mathrm{ml}$ of distilled water. Gerboxes were placed in incubation chamber at temperatures adjusted of each treatment. The first germination count was performed at 10 days and final at 28 days, where normal seedling with hypocotyl $\geq 2 \mathrm{~cm}$ was considered germinated seed.

Radicle protrusion: performed with four replications of 100 seeds according to the germination test. The number of seeds with radicle protrusion $\geq 2 \mathrm{~mm}$ was estimated.

Germination speed index: calculated according to formula adapted by Maguire (1962); where daily counts of seeds that issued radicle for 28 days were carried out:

GSI $=\left(\mathrm{G}_{1} / \mathrm{N}_{1}+\mathrm{G}_{2} / \mathrm{N}_{2}+\ldots+\mathrm{G}_{\mathrm{n}} / \mathrm{N}_{\mathrm{n}}\right)$, where:

$\mathrm{GSI}=$ germination speed index

$G_{1}, G_{2}$ and $G_{n}=$ number of seeds with radicle protrusion determined in the first, second, ... and last count.

$\mathrm{N}_{1}, \mathrm{~N}_{2}$ and $\mathrm{N}_{\mathrm{n}}=$ number of days of test in the first, second,. and last count.

Tetrazolium test: performed with seeds that did not germinate in the germination test. Staining was performed with of 2,3,5 triphenyl tetrazolium chloride solution at concentrations of $0.075 \%$ for 6 hours in the dark at $35^{\circ} \mathrm{C}$. After this period, seeds were washed in running water and individually analyzed to determine viability.

Stage 2 - Assessing the presence of thermoinhibition and/or thermodormancy in parsley seeds: In this stage, three temperature conditions were evaluated: ideal, critical and transfer from critical to ideal (after 6 days of test implementation, period near stage 3 of imbibition), 3 parsley cultivars (Graúda Portuguesa, Lisa Preferida and Chácara), to determine thermoinhibition and/or thermodormancy in the species being studies. Temperatures were determined based on the results obtained in the first stage. The germination capacity of seeds was determined by the same tests used in stage 1 .
The experimental design of the first stage was completely randomized (CRD), consisting of seven treatments (temperatures) with 4 replicates; the second stage was carried out in CRD experimental design in a $3 \times 3$ factorial scheme consisting of 3 parsley cultivars and 3 temperature conditions for germination with 4 replicates. The mean values of results were compared by the Tukey test at $p>0,05$ significance.

\section{RESULTS AND DISCUSSION}

In the first stage of the experiment, the germination of parsley seeds showed a decreasing behavior when raising temperature above $20^{\circ} \mathrm{C}$, considered the temperature that allowed maximum seed performance, but not significantly differing from temperatures of 10,25 and $30-20^{\circ} \mathrm{C}$ (Table 1); a similar situation occurred in fennel seeds, when the effect of temperature on the physiological potential was studied (STEFANELLO et al., 2006).

Temperatures of 30 and $35{ }^{\circ} \mathrm{C}$ were not ideal for the germination of parsley seeds with $26.50 \%$ and $0.25 \%$, respectively (table 1 ), with a decrease in root protrusion and germination speed index, significantly differing from all other treatments; and these results are similar to those obtained in the germination of carrot seeds (CARNEIRO; GUEDES, 1992) and coriander seeds (PEREIRA et al., 2005), where temperatures of 15$25^{\circ} \mathrm{C}$ resulted in higher germination, while higher temperatures were harmful.

The highest germination speed was obtained at $25^{\circ} \mathrm{C}$, compared with other treatments (table 1). According to Carvalho and Nakagawa (2012), the effect of temperature on the germination speed differs slightly from that observed on total germination; the optimum temperature for total germination is different from the germination speed, and temperatures above optimum temperature for total germination accelerate the process speed, but disorganize it, so the number of seeds that achieve germination decreases rapidly.

Seeds that did not germinate at $35^{\circ} \mathrm{C}$ remained viable, being demonstrated by the tetrazolium test, which was the method used in the second stage of the experiment to study the behavior of seeds of this species at high temperatures, considering ideal temperature of $20^{\circ} \mathrm{C}$ and critical of $35^{\circ} \mathrm{C}$. 
Table 1. Germination percentage, radicle protrusion and germination speed index of parsley seeds (Petroselinum crispum) at different temperatures.

\begin{tabular}{cccc}
\hline Temperature & Germination percentage $(\%)$ & Radicle protrusion $(\%)$ & GSI \\
\hline 10 & $76,50 \mathrm{ab}$ & $84,00 \mathrm{ab}$ & $2,3735 \mathrm{~b}$ \\
20 & $89,25 \mathrm{a}$ & $91,50 \mathrm{a}$ & $2,6130 \mathrm{~b}$ \\
25 & $69,25 \mathrm{ab}$ & $85,00 \mathrm{ab}$ & $3,4945 \mathrm{a}$ \\
30 & $26,50 \mathrm{c}$ & $37,50 \mathrm{c}$ & $1,2230 \mathrm{c}$ \\
35 & $0,25 \mathrm{~d}$ & $0,50 \mathrm{~d}$ & $0,0107 \mathrm{~d}$ \\
$20-30$ & $60,50 \mathrm{~b}$ & $81,00 \mathrm{ab}$ & $2,6147 \mathrm{~b}$ \\
$30-20$ & $69,25 \mathrm{ab}$ & $76,00 \mathrm{~b}$ & $2,2872 \mathrm{~b}$ \\
\hline $\mathrm{CV}(\%)$ & 16,17 & 10,00 & 16,39
\end{tabular}

In the second stage of the experiment, seeds of Graúda Portuguesa, Lisa Preferida and Chácara cultivars showed greater physiological response at $20^{\circ} \mathrm{C}$, verified by the percentage of radicle protrusion, seed germination and germination speed index (Figure 1).

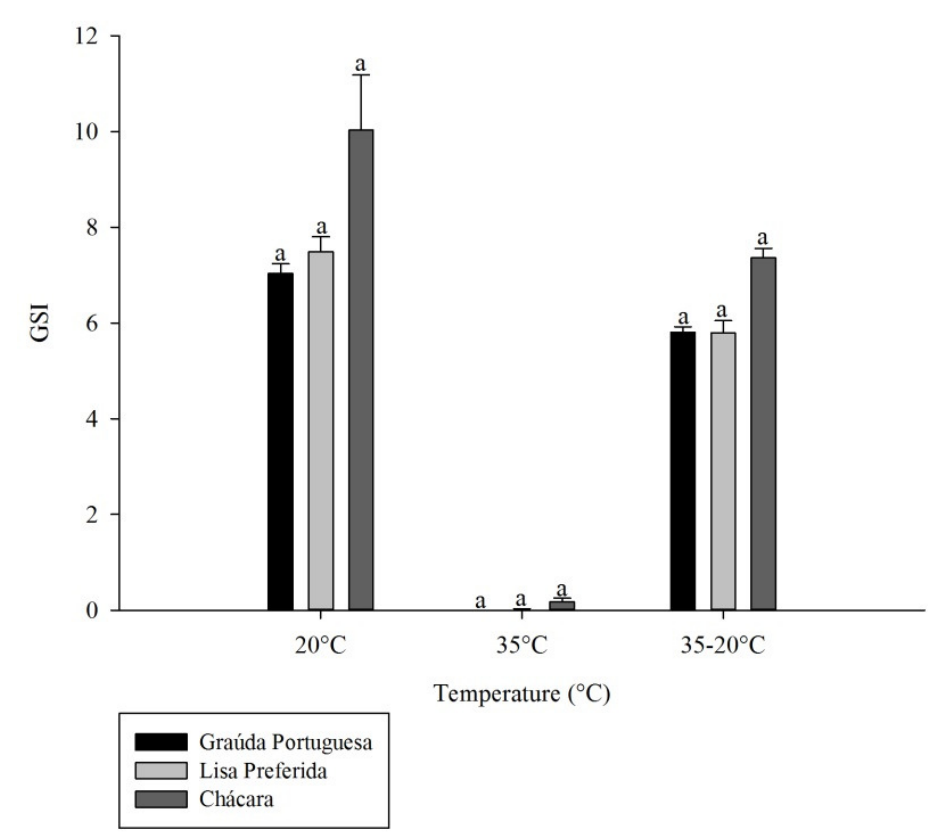

Figure 1. Germination speed index (GSI) of parsley seeds of Graúda Portuguesa, Lisa Preferida and Chácara cultivars at different temperatures

At $35{ }^{\circ} \mathrm{C}$, the percentage of radicle protrusion and germination of parsley seeds of three cultivars reduced (figure 2), also reducing the germination rate, reaching values close to zero. Similar results were found in different carrot cultivars, where temperature of $35^{\circ} \mathrm{C}$ drastically reduced the physiological potential of seeds (PEREIRA et al., 2007). According to Delouche (2004), temperature is considered the most influential factor on the speed and percentage of germination.

Three possible causes can be related to the loss of germination capacity of seeds at high temperatures: germination inhibition (thermoinhibition); occurrence of secondary dormancy (thermodormancy); and/or loss of seed viability

When seeds were submitted to temperature of $35^{\circ} \mathrm{C}$ and then transferred to $20^{\circ} \mathrm{C}$, high germination percentage was observed, similar to treatment with temperature considered optimal $\left(20^{\circ} \mathrm{C}\right)$, a result observed for Chácara cultivar and slightly lower values for the other two cultivars, but well above those obtained at $35^{\circ} \mathrm{C}$ (Figure 3), thus showing the possible occurrence of thermoinhibition in parsley seeds at high temperatures. Thermoinhibition has been studied in seeds of other parsley family species (Apiaceae) such in carrot (CARNEIRO; GUEDES, 1992; PEREIRA et al, 


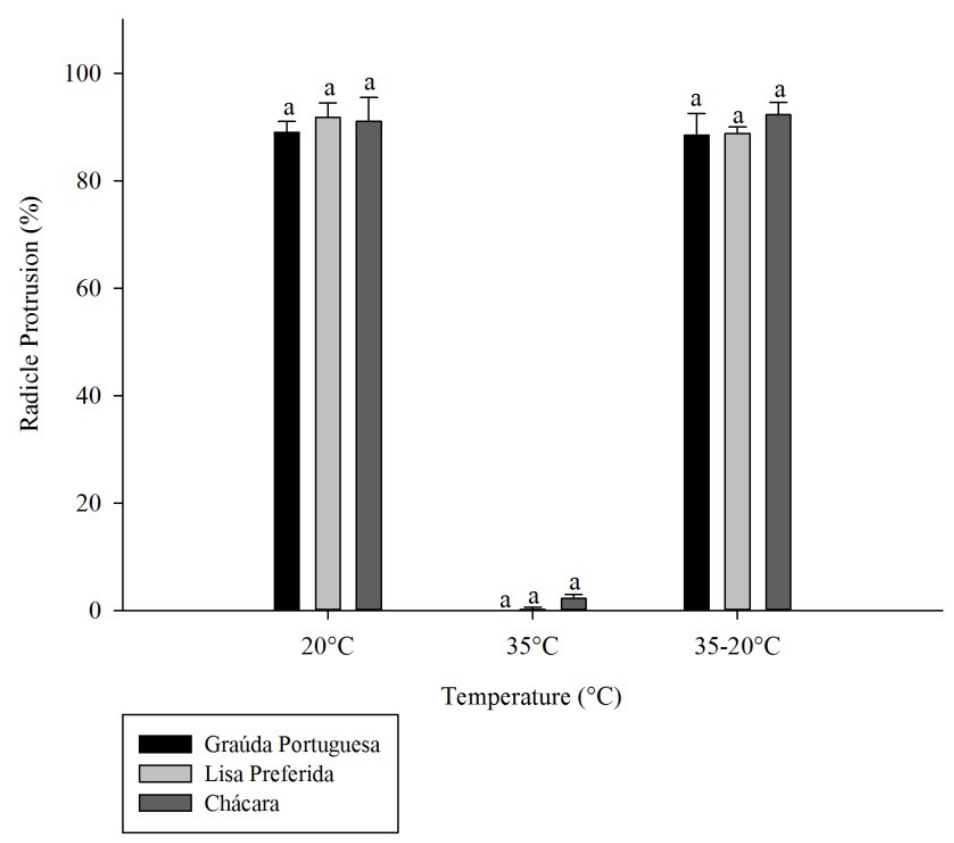

Figure 2. Radicle protrusion of parsley seeds of Graúda Portuguesa, Lisa Preferida and Chácara cultivars at different temperatures.

Lettuce is the leafy vegetable species with more information on germination inhibition at high temperatures. According to Kozarewa et al. (2006), when lettuce seeds are exposed to high temperatures during imbibition, there may be temporary (thermoinhibition) or complete germination inhibition, in which seeds do not germinate even after lowering temperature (thermodormancy). Several studies have reported the causes of this sensitivity and the existence of a close link between endosperm weakening, activity of endo- $\beta$ mannanase enzyme, ethylene production, heattolerant proteins such as heat shock proteins (HSP) and germination of lettuce seeds under high temperatures (NASCIMENTO; CANTLIFFE, 2002; NASCIMENTO et al., 2004; SCHWEMBER; BRADFORD, 2010; CATÃO et al., 2014).

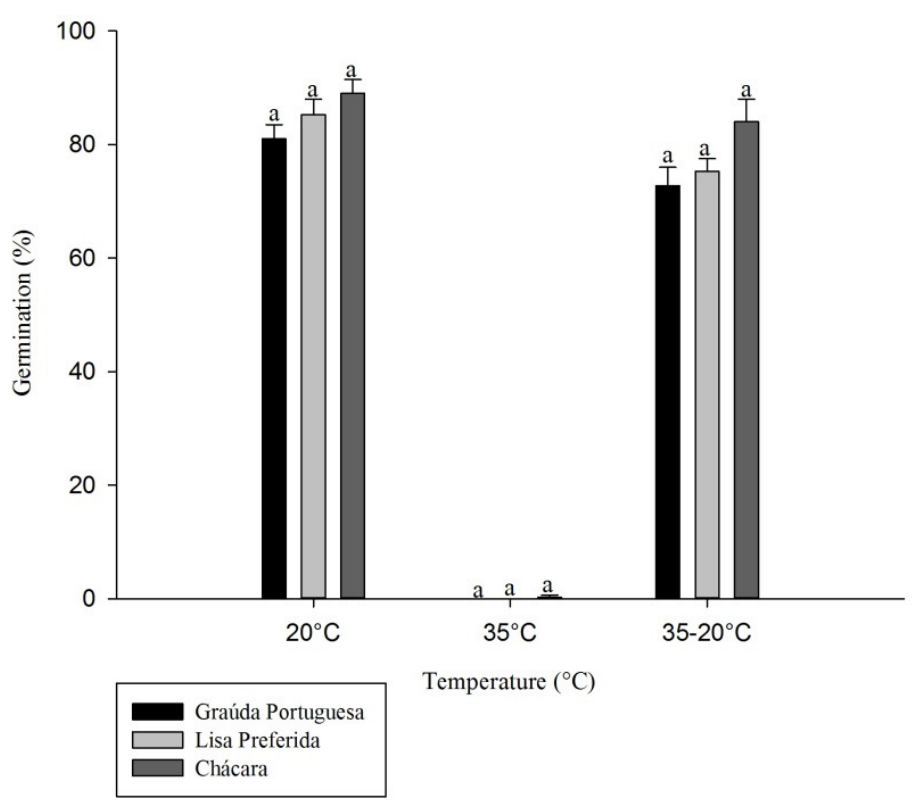

Figure 3. Germination percentage of parsley seeds of Graúda Portuguesa, Lisa Preferida and Chácara cultivars at different temperatures. 
Other authors have focused their studies on sensitivity to high temperatures of germinating seeds with hormonal balance. According to Gonai et al. (2004) in lettuce seeds and Toh et al. (2008) in Arabdopsis seeds, the maximum germination temperature primarily determined through antagonistic interactions of gibberellin (GA) and abscisic acid (ABA). Work conducted with lettuce have shown that the ABA content is maintained at very high levels when seeds are imbibed at high temperatures, but rapidly decreases as imbibition occurs at optimum temperatures for germination (ARGYRIS et al 2008b).

The knowledge about thermodormancy of lettuce seeds is advancing with studies on genes related to this feature. Clemente et al (2015) studied the expression of genes associated with biosynthetic pathways of abscisic acid, gibberellin and ethylene during lettuce seeds germination and found genes exclusive of dormant seeds.

It can be assumed that some of these mechanisms are involved in thermoinhibition of parsley seeds, but further studies aimed to clarify this process occurred at high temperatures are necessary.

Studies on the sensitivity of parsley seeds at high temperatures are scarce and so far, one cannot yet elucidate which mechanism would be involved in the incapacity of seeds to germinate under these conditions, but the identification of the presence of thermoinhibition presented in this work supports further research.

\section{CONCLUSIONS}

Temperature has an effect on the germination process of parsley seeds, and the ideal temperature is $20^{\circ} \mathrm{C}$; higher temperatures tend to cause a decrease in the germination capacity.

Seeds of Graúda Portuguesa, Lisa Preferida and Chácara cultivars that do not germinate at $35^{\circ} \mathrm{C}$ temperature begin to germinate when there is a decrease in temperature to $20^{\circ} \mathrm{C}$.

Parsley seeds show thermoinhibition at high temperatures.

RESUMO: A temperatura pode exercer grande influência na germinação, sendo considerada ótima aquela em que a semente expressa seu potencial máximo de germinação no menor período de tempo. A germinação das sementes de salsa é lenta, irregular e desuniforme. O objetivo do trabalho foi determinar se há ocorrência de termodormência ou de termoinibição em sementes de salsa em função da variação da temperatura. $\mathrm{O}$ delineamento experimental da primeira etapa foi inteiramente casualizado (DIC), constituído por 7 temperaturas, com 4 repetições e a segunda etapa em esquema fatorial 3x3, constituído por 3 cultivares de salsa e 3 temperaturas para germinação com 4 repetições. As sementes das cultivares estudadas não germinaram em temperaturas de $35^{\circ} \mathrm{C}$. Sementes de salsa apresentam termoinibição em temperaturas elevadas, sendo necessário elucidar os mecanismos que estão envolvidos nesse processo.

PALAVRAS CHAVE: Temperatura. Potencial Fisiológico. Petroselinum crispum.

\section{REFERENCES}

ARGYRIS, J. M.; DAHAL, P.; HAYASHI, E.; STILL, D. W.; BRADFORD, K. J. Genetic variation for lettuce seed thermoinhibition is associated with temperature-sensitive expression of abscisic acid, gibberellin, and ethylene biosynthesis, metabolism, and response genes. Plant Physiol. v. 148: p. 926-947,

2008b. https://www.ncbi.nlm.nih.gov/pubmed/18753282.

BEWLEY, J. D.; BRADFORD, K. J.; HILHORST. H. W. M.; NONOGAKI, H. Seeds: Physiology of development, germination and dormancy (3 ed.), 2013. 392p.

BRASIL. Ministério da Agricultura, Pecuária e Abastecimento. Regras para análise de sementes. Brasília: Mapa/ACS, 2009. 399p.

CARNEIRO, J. W. P.; GUEDES, T. A. Influência da temperatura no desempenho germinativo de sementes de cenoura (Daucus carota L.) avaliada pela função de distribuição de Weibull. Revista Brasileira de Sementes. v. 14: p. 207-213, 1992. http://dx.doi.org/10.17801/0101-3122/rbs.v14n2p207-213. 
CARVALHO, N. M; NAKAGAWA, J. Sementes: ciência, tecnologia e produção. 5.ed. FUNEP: Jaboticabal, 2012. 590p.

CATÃO, H. C. R. M.; GOMES, L. A. A.; SANTOS, H. O.; GUIMARÃES, R. M.; FONSECA, P. H. R.; CAIXETE, F. Aspectos fisiológicos e bioquímicos da germinação de sementes de alface em diferentes temperaturas. Pesquisa agropecuária brasileira, Brasília, v.49, n.4, p.316-322, 2014.

http://dx.doi.org/10.1590/S0100-204X2014000400010

CLEMENTE, A. C. S.; GUIMARÃES, R. M.; MARTINS, D. C.; GOMES, L. A. A.; CAIXETA, F.; REIS, F. G. E.; ROSA, S. D. V. F. Expression of genes associated with the biosynthetic pathways of abscisic acid, gibberellin, and ethylene during the germination of lettuce seeds. Genetics and Molecular Research, v. 14, n.2, p. 4703-4715, 2015. http://dx.doi.org/10.4238/2015.May.11.3 .

DELOUCHE, J. C. O problema nem sempre é a qualidade das sementes. Revista SeedNews, Brasília, DF, v. 8, p. 42, 2004.

DINIZ, F. O.; MOREIRA, F. J. C.; SILVA, F. D. B.; MEDEIROS FILHO, S. Influence of light and temperature in the germination of oiticica (Licania rígida Benth.) seeds. Revista Ciência Agronômica, v. 29, p. 476-480, 2008.

https://www.researchgate.net/publication/294866519_Influence_of_light_and_temperature_in_the_germination _of_oiticica_Licania_rigida_Benthseeds

FERREIRA, E. G. B. S.; MATOS, V. P.; SALES, A. G. A.; PACHECO, M. V. Influência da temperatura e do substrato na germinação e desenvolvimento inicial de plântulas de rúcula (Eruca sativa Mill.). Revista

Brasileira de Ciências Agrárias, v. 3, p. 209-212, 2008. http://dx.doi.org/10.5039/agraria.v3i3a234.

\section{FILGUEIRA, F. A. R. Novo manual de olericultura: agrotecnologia moderna na produção e} comercialização de hortaliças. Viçosa: UFV, 2008. 319p.

GONAI, T.; KAWAHARA S.; TOUGOU, M.; SATOH, S.; HASHIBA, T.; HIRAI, N.; KAWAIDE, H.; KAMIYA, Y.; YOSHIOKA, T. (2004). Abscisic acid in the thermoinhibition of lettuce seed germination and enhancement of its catabolism by gibberellin. Journal Experimental Botany, v. 55, p. 111-118, 2004. http://dx.doi.org/10.1093/jxb/erh023.

KHAN, A. A. Hormonal regulation of primary and secondary seed dormancy. Israel Journal of Botany, v. 29, p. 207-224, 1980/81.

http://www.tandfonline.com/doi/abs/10.1080/0021213X.1980.10676889?journalCode=tips19.

KOZAREWA, I.; CANTLIFFE, D. J.; NAGATA, R. T.; STOFFELLA, P. J. High maturation temperature of lettuce seeds during development increased ethylene production and germination at elevated temperatures.

Journal of the American Society of Horticultural Science, v.131, p.564-570, 2006.

http://journal.ashspublications.org/content/131/4/564.full.pdf.

MACHADO, C. F.; OLIVEIRA, J. A.; DAVIDE, A.C.; GUIMARÃES, R.M. Metodologia para a condução do teste de germinação em sementes de ipê-amarelo (Tabebuia serratifolia (Vahl) Nicholson). Cerne, Lavras, v.8, n.2, p.17-25, 2002.

http://www.sifloresta.ufv.br/bitstream/handle/123456789/18216/Cerne_v8_n2_p1725_2002.pdf?sequence=1\&i sAllowed=y

MAGUIRE, J. D. Speed of germination: aid in selection and evaluation for seedling emergence and vigour.

Crop Science, v. 2, p. 176-177, 1962.

https://dl.sciencesocieties.org/publications/cs/abstracts/2/2/CS0020020176/.

NASCIMENTO, W. M.; CANTLIFFE, D. J. Germinação de sementes de alface sob altas temperaturas.

Horticultura Brasileira, v. 20, n. 1, p. 103- 106, 2002. http://dx.doi.org/10.1590/S0102-05362002000100020. 
NASCIMENTO, W. M.; CANTLIFFE, D. J.; HUBER, D. J. Ethylene evolution and endo-b-mannanase activity during lettuce seed germination at high temperature. Scientia Agricola (Piracicaba, Braz.), v. 61, n. 2, p. 156163, 2004. http://www.scielo.br/scielo.php?script=sci_arttext\&pid=S0103-90162004000200006.

NASCIMENTO, W. M. Produção de sementes de hortaliças para a agricultura familiar. Brasília: Embrapa Hortaliças, 2005. 16p. (Circular técnica, 35). https://ainfo.cnptia.embrapa.br/digital/bitstream/CNPH2009/30295/1/ct_35.pdf .

PEREIRA, R. S.; MUNIZ, M. F. B.; NASCIMENTO, W. M. Aspectos relacionados à qualidade de sementes de coentro. Horticultura Brasileira, v. 23, p. 703-706, 2005.

http://www.scielo.br/scielo.php?script=sci_arttext\&pid=S0102-05362005000300002.

PEREIRA, R. S.; NASCIMENTO, W.M.; VIEIRA J. V. Germinação e vigor de sementes de cenoura sob condições de altas temperaturas. Horticultura Brasileira, v. 25, p. 215-219, 2007.

http://www.scielo.br/scielo.php?script=sci_arttext\&pid=S0102-05362007000200017.

PILL, W. G.; KILIAN, E. Germination and emergence of parsley in response to osmotic or matric seed priming and treatment with gibberellin. HortSciense, v. 35, p. 907-909, 2000.

http://hortsci.ashspublications.org/content/35/5/907.full.pdf.

RODRIGUES, A. P. D. C.; LAURA, V. A.; CHERMOUTH K. S.; GADUM, J. Absorção de água por semente de salsa, em duas temperaturas. Revista Brasileira de Sementes, v. 30, p. 49-54, 2008.

http://www.scielo.br/scielo.php?script=sci_arttext\&pid=S0101-31222008000100007.

SCHWEMBER, A. R.; BRADFORD, K. J. A genetic locus and gene expression patterns associated with the priming effect on lettuce seed germination at elevated temperatures. Plant Molecular Biology, v. 73, p. 105118, 2010. https://link.springer.com/article/10.1007/s11103-009-9591-x .

SILVA, G. O.; VIEIRA, J. V.; NASCIMENTO, W. M.; BOITEUX, L. S. Estratégias de seleção para germinação de sementes de cenoura em condições de temperaturas elevadas. Revista Ceres, Viçosa, v. 58, n. 1, p. 121-125, 2011. http://www.scielo.br/scielo.php?script=sci_arttext\&pid=S0034-737X2011000100018.

STEFANELLO, R.; GARCIA, D. C.; MENEZES, N. L.; MUNIZ, M. F. B.; WRASSE, C. F. Efeito da luz, temperatura e estresse hídrico no potencial fisiológico de sementes de funcho. Revista Brasileira de Sementes, v. 28, n. 2, p. 135-41, 2006. http://dx.doi.org/10.1590/S0101-31222006000200018

STEINER, F.; PINTO JUNIOR, A. S.; ZOZ, T.; GUIMARÃES, V. F.; DRANSKI, J. A. L.; RHEINHEIMER, A. R. Germinação de sementes de rabanete sob temperaturas adversas. Revista Brasileira de Ciências Agrárias, v. 4, p. 430-434, 2009.

http://www.agraria.pro.br/sistema/index.php?journal=agraria\&\%20page=article\&op=viewArticle $\&$ path $\% 5 \mathrm{~B} \%$ $5 \mathrm{D}=606$.

TOH, S.; IMAMURA, A.; WATANABE, A.; NAKABAYASHI, K.; OKAMOTO, M.; JIKUMARU, Y.; HANADA, A.; ASO, Y.; ISHIYAMA, K.; TAMURA, N.; IUCHI, S.; KOBAYASHI, M.; YAMAGUCHI, S.; KAMIYA, Y.; NAMBARA, E.; KAWAKAMI, N. High temperature-induced abscisic acid biosynthesis and its role in the inhibition of gibberellin action in Arabidopsis seeds. Plant Physiol, v. 146, p. 1368-1385, 2008. http://dx.doi.org/10.1104/pp.107.113738. 